\title{
A Study on Evaluation of Capital Structure
}

\author{
G.D.V. Kusuma ${ }^{1}$ \\ ${ }^{1}$ Department of MBA-Sree Kavitha Institute of Management, India. \\ Correspondence: Dr. G.D.V. Kusuma, Department of MBA-Sree Kavitha Institute of Management, India.
}

Received: October 20, $2018 \quad$ Accepted: October 28, $2018 \quad$ Online Published: November 2, 2018

\begin{abstract}
Capital is the back bone of any organization. Everyone should utilize the capital in a proper way; otherwise their business will be washed away from the market. The present paper is an attempt to present the capital structure of My Home Industries Ltd. In this paper the researcher/s made an attempt to evaluate the capital structure by considering different elements like debt and equity.
\end{abstract}

Keywords: Capital, Debt, Evaluation, Equity, Structure, My Home Industries Ltd., Hyderabad.

\section{Introduction}

The financial decisions taken by the management of the companies is highly important while determining the optimal capital structure. It is responsibility of the management to design their capital structure in a way to maximize their firm value. However, firms have a different level of leverage and managers try to achieve the best set to attain an optimal capital structure. MM (1958) argues that under very restrictive assumptions of perfect capital markets, investor's homogenous expectations, tax free economy and no transaction cost, capital structure is irrelevant in determining firm value. The present paper is arranged as follows. The next session presents the methodology of the study, and the last session projects the empirical results of the analysis, findings and suggestions that are based on the results of the study.

Primary Data: Primary data is data that has not been previously published, i.e., the data is derived from a new or original research study and collected at the source.

Secondary Data: This type of data is generally taken from newspapers, magazines, bulletins, reports, journals etc. The present study is entirely based on secondary data i.e. financial reports of the company.

2. Objectives of the Study

- To study different sources of finance available to the firm for its operations.

- $\quad$ To Study the EPS under different years i.e. from 2010-11 to 2014-15.

- To measure the liquidity of the firm through ratios

- To project how to take account of a firm's financing mix in evaluating investment decisions

\section{Results and Discussion}

Table -1 Capital Structure of My Home Industries Limited (Rs. in Lakhs)

\begin{tabular}{llllll}
\hline Particulars & $\mathbf{2 0 1 0 - 1 1}$ & $\mathbf{2 0 1 1 - 1 2}$ & $\mathbf{2 0 1 2 - 1 3}$ & $\mathbf{2 0 1 3 - 1 4}$ & 2014-15 \\
\hline I. Authorized capital & & & & & \\
\hline Equity shares & 550 & 550 & 550 & 550 & 550 \\
\hline II. Issued sharers & 550 & 550 & 550 & 550 & 550 \\
\hline III. Reserves \&surplus & & & & \\
\hline
\end{tabular}




\begin{tabular}{llllll}
\hline 1.share premium & 1487.5 & 1487.5 & 1487.5 & 1487.5 & 1487.5 \\
\hline 2.capital reserve & 48.18 & 48.18 & 48.18 & 48.18 & 48.18 \\
\hline $\begin{array}{l}\text { 3.capital investment } \\
\text { subsidy }\end{array}$ & 30 & 30 & 30 & 30 & 30 \\
\hline 4.General reserve & 6059.7 & 4848.93 & 5848.93 & 5998.93 & 6228.93 \\
\hline
\end{tabular}

The above table illustrates about the capital structure of the company from 2010-11 to 2014-15. The Equity shares of the company are constant during the entire period of the study i.e. (Rs. 550 Lakhs), from $2010-2015$, apart from that the capital reserves of the company are also consistent during the study period. The company is maintaining its reserves \&surplus from 2010-2015 including share premium and Capital reserves. The company's general reserve is changing from year to year and the highest GR shows in the financial year 2014-15 i.e. Rs. 6228.93Lakhs.

Table - 2 Debt Capital of the Company (Rs. In Lakhs)

\begin{tabular}{llllll}
\hline Loans \& Funds & $\mathbf{2 0 1 0 - 1 1}$ & $\mathbf{2 0 1 1 - 1 2}$ & $\mathbf{2 0 1 2 - 1 3}$ & $\mathbf{2 0 1 3 - 1 4}$ & $\mathbf{2 0 1 4 - 1 5}$ \\
\hline I. Secured Loans & & & & & \\
\hline A. Term loans \& W.C. borrowing from Bank & 7996.6 & 8228.6 & 10280 & 13077 & 15284 \\
\hline II. Unsecured Loans & 2283.4 & 2093.3 & 1432.1 & 4047.5 & 877.7 \\
\hline
\end{tabular}

From the above data it is evident that the company's secured loans are increasing continuously during the period of the study i.e. from 2010-15. It also projects that the unsecured loans are not consistent during the years 2010-15. These unsecured loans are changing from year to year. During the years 2013-15, the values of secured loans are very high (i.e. Rs.13077 Lakhs \& Rs. 15284). Where as the unsecured loans are showing extremely high during the year 2013-14 i.e. Rs. 4047.5

Table -3 Growths of Owners Funds (Rs. In Lakhs)

\begin{tabular}{llll}
\hline Years & Equity share capital & Reserve \& surplus & Net worth \\
\hline $2010-11$ & 550 & 7685 & 8235 \\
\hline $2011-12$ & 550 & 6470 & 7020 \\
\hline $2012-13$ & 550 & 7559 & 8109 \\
\hline $2013-14$ & 550 & 8353 & 8903 \\
\hline $2014-15$ & 550 & 9225 & 9775 \\
\hline $2010-11$ & 550 & 7685 & 8235 \\
\hline
\end{tabular}

The above represents the growths of owner's funds for the years 2010-15. The company's equity share capital is constant during the entire period of the study i.e. 2010-11 to 2014-15. It is observed from the above data that the net worth of the company is gradually increasing from 2011-15 (i.e. from Rs. 7020 to Rs. 977 Lakhs), which indicates the good performance of the company. This indicates the earnings and savings potentiality of the company, and the company is suggested to maintain the same in the future.

Table - 4 Growth Of Debt Capital (Rs. In Lakhs)

\begin{tabular}{llll}
\hline Year & Secured loans & Unsecured loans & Total debt \\
\hline $2010-11$ & 7996.55 & 2283.43 & 10279.98 \\
\hline $2011-12$ & 8228.56 & 2093.25 & 10321.81 \\
\hline $2012-13$ & 10280.35 & 1432.13 & 11712.4 \\
\hline $2013-14$ & 13077.04 & 4047.47 & 17124.51 \\
\hline $2014-15$ & 15284.48 & 877.71 & 16162.19 \\
\hline
\end{tabular}

The above table represents the growth of debt capital of the company. The company's debt capital is increased during the period of the study. It is not a good sign to the company because it increases the company's risk. This shows that the liquidity position of the company is not in a good position and hence the company has to reduce its debt capital in order to maintain the desirable norm of current ratio i.e. 2:1 
Table- 5 Debt Equity Ratios (Rs. In Lakhs)

\begin{tabular}{llll}
\hline Years & Debt & Equity (net worth) & Ratio \\
\hline $2010-11$ & 10279.98 & 8234.64 & 1.24838 \\
\hline $2011-12$ & 10321.81 & 7020.11 & 1.47032 \\
\hline $2012-13$ & 11712.48 & 8108.72 & 1.44443 \\
\hline $2013-14$ & 17124.51 & 8903.24 & 1.92340 \\
\hline $2014-15$ & 16162.19 & 8775.21 & 1.65340 \\
\hline
\end{tabular}

It is clear from the above depicted graph that debt equity ratio of the net worth was approximately 1.24 times in the year 2012. And it is increased to 1.92 times in the year 2013-14 and suddenly decreased 1.65 in the year 2014-15. From this it is clear that debt equity ratio is not consistent and it is in unpredictable manner.

Table - 6 Interest Coverage Ratio (Rs. In Lakhs)

\begin{tabular}{llll}
\hline Year & EBIT & INT & I.C.R \\
\hline $2010-11$ & 3352.86 & 1118.37 & 2.998 \\
\hline $2011-12$ & 3385.02 & 1038.45 & 3.260 \\
\hline $2012-13$ & 4240.58 & 896.83 & 4.728 \\
\hline $2013-14$ & 4185.45 & 1082.33 & 3.867 \\
\hline $2014-15$ & 4269.01 & 1159.13 & 3.683 \\
\hline
\end{tabular}

The above information projects the interest coverage ratio of the company. Interest coverage ratio has been calculated for the years 2010-11 to 2014-15. The calculated ICR is very low from the starting year i.e. 2011-12 (2.998 lakhs), it is increased in the year 2012-13 (4.728 Lakhs), and in the years 2013- 14 and 2014-15 it was decreased (3.683 lakhs).

Table - 7 Return On Networth (Rs. In Lakhs)

\begin{tabular}{lllll}
\hline Years & Net profit & Net worth & R.O.N & \% \\
\hline $2010-11$ & 781.47 & 8234.64 & 0.09 & 9 \\
\hline $2011-12$ & 888.74 & 7020.11 & 0.13 & 13 \\
\hline $2012-13$ & 1398.84 & 8108.72 & 0.17 & 17 \\
\hline $2013-14$ & 1042.71 & 8903.24 & 0.12 & 12 \\
\hline $2014-15$ & 1122.61 & 9775.15 & 0.11 & 11 \\
\hline
\end{tabular}

The above chart illustrates the net worth position of the company for the years 2010-11 to 2014-15. Here Net profit \& Net worth bas been taken for calculating the RON. During the period of the study the RON is in fluctuating manner and is lowest in the year 2010-11 i.e. $9 \%$ and it is highest in the year 2012-13 i.e. $17 \%$.

Table - 8 Earning Per Share (Rs. In Lakhs)

\begin{tabular}{rlllr}
\hline Years & Net profit & No of shares & E.P.S & \% \\
\hline $2010-11$ & 781.47 & $55,00,000$ & 142.09 & 14.21 \\
\hline $2011-12$ & 888.74 & $55,00,000$ & 161.59 & 16.16 \\
\hline $2012-13$ & 1398.84 & $55,00,000$ & 254.33 & 25.43 \\
\hline $2013-14$ & 1042.71 & $55,00,000$ & 189.58 & 18.96 \\
\hline $2014-15$ & 1122.61 & $55,00,000$ & 204.01 & 20.04 \\
\hline
\end{tabular}


From the above table it is observed that Net worth earnings per share in the year 2010-11 is (142.09), it is increased in the year 2012-13 (254.33), finally it decreased in the year 2013-14 (204.1) and there is a slight increase in the year 2014-15.

4. Findings

- Debt equity ratio reveals that the company employed more amount of debt for raising the funds. The debt equity ratio was approximately 1.24 times and increased to 1.92 times in the year 2014-15 which is not a good sign to the company.

- The interest coverage ratio in the year 2010-11 is 2.99 indicating that the firm has very low debt servicing capacity. The interest coverage ratio is high in the year 2012-2013 and indicates that the firm has sufficient earning to cover the interest charges. Company's ability to service the debt has increased over the period of study.

- The return on net worth is high in the year $2011-13$ by $17 \%$ indicating that the firm earned greater returns on their investment.

- The company's turnover position is gradually increasing every year from 2010-11 to 2014-15.

- The net profit of the firm is growing during the period of the study and indicates the good operational efficiency of the firm.

- The net worth of the firm is in increasing manner for the years 2010-2013, and it is in fluctuating manner from 2013 -2014 onwards.

\section{Suggestions}

- The company has to maintain the optimal capital structure so that it can contribute to the wealth of the shareholders in the coming years.

- My Home Industries should exercise more to control over its outside purchases and overheads which have effect on the profitability of the Company.

- The company is advised to increase its profitability in order to meet various expenses.

- My Home Industries Ltd., reserves are increasing every year. Therefore proper utilization of these reserves should be done by the management of the Company, by giving bonus shares to the existing shareholders etc.

References

Arbabiyan, Ali-Akbar \& Safari, Mehdi, (2009), The effects of capital structure and profitability in the listed firms in Tehran Stock Exchange, Journal of Management Perspective, 33: 159-175.

Abor,J (2005), The effect of capital structure on profitability : an empirical analysis of listed firms in Ghana, Journal of Risk Finance, 6: 438-447.

Boodhoo, Roshan (2009), Capital Structure and performance of Mauritius Listed Firms: Theoretical and Empirical Evidences, Online Web http://www.nyu.edu/classes/keefer/EvergreenEnergy/boodhoorebook.pdf

Bradley M. Jarell GA, \& Kim EH (1984), On the existence of an Optimal Capital Structure: The Theory and Evidence, . Journal of finance, 39: 857-880.

Berger, A \& Bonaccorsi di Patti, E (2006), Capital structure and firm performance: a new approach to testing agency theory and an application to the banking industry, Journal of Banking and Finance, 32: 1065-1102.

Chakraborty, I., (2010). Capital structure in an emerging stock market: The case of India, Research in International Business and Finance, 24: 295-314.

Champion, D. (1999), Finance: the joy of leverage, Harvard Business Review, Vol. 77, pp. 19-22.

Chen JJ. (2004), Determinants of Capital Structure of Chinese Listed Companies, Journal of Business Research, 57: 1341-1351.

Deesomsak R, Paudyal K \& Pescetto G (2004), The determinants of capital structure: Evidence from the Asia Pacific region, Journal of Multinational Financial Management, 14: 387-405.

Ebaid I E, (2009), The impact of capital structure choice on firm performance: empirical evidence from Egypt, The Journal of Risk Finance, 10(5): 477 -487.

Harris M, and Raviv R. (1991), The Theory of Capital Structure, Journal of Finance, 46 (1): 297-355.

Heinkal, Robert (1982), A theory of capital structure relevance under imperfect information, Journal of Finance, 37: 1141-1150.

Hovakimian, A., Hovakimian, G., \& Tehranian, H. (2004), Determinants of target capital structure: The case of dual debt and equity issues, Journal of financial economics, 71(3),517-540.

Majumbar, S and Chhibber, P (1999), Capital structure and performance: evidence from a transition economy on an aspect of corporate governance, Public Choice, 98: 287-305. Miller, M (1977), Debt and Taxes, Journal of Finance, 32: 262-275. 
Modigliani, F and Miller, M (1963), Corporate income taxes and cost of capital: a correction, American Economic Review, 53: 443-453.

Myers, S. (1977), Determinants of corporate borrowings, Journal of Financial Economics, 5: 147-175. Pathak Rajesh (2011), Capital Structure and Performance: Evidence from Indian Manufacturing Firms, Social Science Research Network, Online Web.

Pratheepkanth. Puwanenthiren, (2011), Capital Structure and Financial Performance: Evidence from Selected Business Companies in Colombo Stock Exchange Sri Lanka, Journal of Arts, Science \& Commerce, II (2): $1-13$.

Ramaswamy, K (2001), Organizational ownership, competitive intensity, and firm performance: an empirical study of Indian manufacturing sectors, Strategic Management Journal, 22: 989-998.

Rajan, R. G., \& Zingales, L. (1995), What do we know about capital structure? Some evidence from international data, Journal of finance, 50(5): 1421-1460.

Razak, N.H.A., Ahmad, R. \& Aliahmed, H.J. (2008), Government ownership and performance: An analysis of listed companies in Malaysia, Corporate Ownership and Control, 6(2): 434-442. 166

Mahfuzah Salim and Raj Yadav / Procedia - Social and Behavioral Sciences 65 ( 2012 ) 156 - 166 Roden, D., Lewellen, W. (1995), Corporate capital structure decisions: evidence from leveraged buyouts, Financial Management, 24: 76-87.

San, O.T. \& Heng, T.B. (2011), Capital Structure and Corporate Performance of Malaysian Construction Sector, International Journal of Humanities and Social Science, 1(2): 28-36.

\section{Copyrights}

Copyright for this article is retained by the author(s), with first publication rights granted to the journal.

This is an open-access article distributed under the terms and conditions of the Creative Commons Attribution license (http://creativecommons.org/licenses/by/4.0/). 